\title{
1 Polar record of Early Jurassic massive carbon injection
}

2

3 Guillaume Suan ${ }^{1,2} \uparrow$, Boris L. Nikitenko ${ }^{3}$, Mikhail A. Rogov $^{4}$, François Baudin ${ }^{5}$, Jorge E.

4 Spangenberg $^{6}$, Valeriy G. Knyazev ${ }^{7}$, Larisa A. Glinskikh ${ }^{3}$, Anna A. Goryacheva ${ }^{3}$, Thierry

5 Adatte $^{1}$, James B. Riding ${ }^{8}$, Karl B. Föllmi ${ }^{1}$, Bernard Pittet ${ }^{2}$, Emanuela Mattioli ${ }^{2}$, and

6 Christophe Lécuyer ${ }^{2,9}$

7

$8 \quad{ }^{1}$ Institut de Géologie et de Paléontologie, Université de Lausanne, Anthropole, CH-1015

9 Lausanne, Switzerland

10

11

12

13

14

15

16

17

18

19

20

21

22

23

24

25

26

27

28

29

30

31

${ }^{2}$ UMR CNRS 5276 LGLTPE, Université Lyon 1, Campus de la Doua, Bâtiment Géode, F69622 Villeurbanne Cedex, France

${ }^{3}$ Institute of Petroleum Geology and Geophysics, Siberian Branch of Russian Academy of Sciences, Ac. Koptyg av.3, Novosibirsk 90, 630090, Russia

${ }^{4}$ Geological Institute of Russian Academy of Sciences, 7 Pyzhevskii Lane, Moscow, 119017, Russia

${ }^{5}$ UMR 7193 iSTeP UPMC-Univ. Paris 06, CNRS, 4 place Jussieu, F-75252 Paris Cedex 05, France

${ }^{6}$ Institute of Mineralogy and Geochemistry, University of Lausanne, Anthropôle, CH-1015

Lausanne, Switzerland

${ }^{7}$ The Institute of Diamond and Precious Metal Geology, Siberian Branch of Russian Academy of Sciences, Lenina av.39, Yakutsk, 677891, Russia

${ }^{8}$ British Geological Survey, Kingsley Dunham Centre, Keyworth, Nottingham NG12 5GG, United Kingdom

${ }^{9}$ Also at Institut Universitaire de France, Paris, France

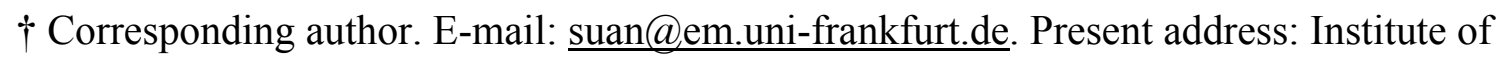
Geosciences, Goethe University Frankfurt, Altenhöferallee 1, D-60438, Frankfurt am Main, Germany

Keywords: Oceanic Anoxic Event, Pliensbachian-Toarcian, carbon isotope excursion, Arctic climate, sea level changes 
The Toarcian Oceanic Anoxic Event (T-OAE) (ca. 182 mya, Early Jurassic) represents one of the best-recognized examples of greenhouse warming, decreased seawater oxygenation and mass extinction. The leading hypothesis to explain these changes is the massive injection of thermogenic or gas hydrate-derived ${ }^{13} \mathrm{C}$-depleted carbon into the atmosphere, resulting in $\mathrm{a}>3$ per mil negative carbon isotope excursion (CIE), accelerated nutrient input and dissolved oxygen consumption in the oceans. Nevertheless, the lack of a precisely dated record of the TOAE outside low latitudes has led to considerable debate about both its temporal and spatial extent and hence concerning its underlying causes. Here we present new isotopic and lithological data from three precisely dated N Siberian sections, which demonstrate that mass extinction and onset of strong oxygen-deficiency occurred near synchronously in polar and most tropical sites and were intimately linked to the onset of a marked 6\% negative CIE recorded by bulk organic carbon. Rock Eval pyrolysis data from Siberia and comparisons with low latitudes show that the CIE cannot be explained by the extent of stratification of the studied basins or changes in organic matter sourcing and suggest that the negative CIE reflects rapid ${ }^{13} \mathrm{C}$-depleted carbon injection to all exchangeable reservoirs. Sedimentological and palynological indicators show that the injection coincided with a change from cold (abundant glendonites and exotic boulder-sized clasts) to exceptionally warm conditions (dominance of the thermophyllic pollen genus Classopollis) in the Arctic, which likely triggered a rapid, possibly partly glacioeustatic sea-level rise. Comparisons with low latitude records reveal that warm climate conditions and poor marine oxygenation persisted in continental margins at least $600 \mathrm{ky}$ after the CIE, features that can be attributed to protracted and massive volcanic carbon dioxide degassing. Our data reveal that the T-OAE profoundly affected Arctic climate and oceanography and suggest that the CIE was a consequence of global and massive ${ }^{13} \mathrm{C}$-depleted carbon injection.

\section{Introduction}

Stable carbon isotope $\left(\delta^{13} \mathrm{C}\right)$ records of carbonate, marine and terrestrial organic carbon show a prominent $>3 \%$ negative carbon isotope excursion (CIE) across an episode of enhanced marine organic carbon deposition termed the Toarcian Oceanic Anoxic Event (TOAE) (Jenkyns, 1988; Hesselbo et al., 2000, 2007; Kemp et al., 2005; Cohen et al., 2007; Hesselbo and Pieńkowski, 2011). The CIE has been interpreted as reflecting a massive injection of ${ }^{13} \mathrm{C}$-depleted carbon, either derived from gas hydrates (Hesselbo et al., 2000; 
Kemp et al., 2005; Cohen et al., 2004, 2007; Hesselbo et al., 2007; Hesselbo and Pieńkowski, 2011) or thermogenic methane (Svenson et al., 2007; Mazzini et al., 2010; but see also Gröcke et al., 2009), to the ocean-atmosphere reservoirs. This injection is thought to have promoted, through enhanced greenhouse conditions, a rise in seawater temperatures larger than $6^{\circ} \mathrm{C}$, widespread oxygen depletion and severe biotic extinctions among marine invertebrates (Wignall et al., 2005; Kemp et al., 2005; Cohen et al., 2007; Gómez et al., 2008; Caswell et al., 2009; Suan et al., 2010; Jenkyns, 2010; Hesselbo and Pieńkowski, 2011; Dera et al., 2011).

Even though the main aspects of the T-OAE are well documented at low latitudes $\left(20-35^{\circ} \mathrm{N}\right)$, very few data are available outside the western margin of the Tethyan Ocean, resulting in large uncertainties concerning the cause of the inferred perturbations (Wignall et al., 2005; van de Schootbrugge et al., 2005; Gómez et al., 2008; McArthur et al., 2008). For instance, several authors have argued that anoxic conditions developed only locally and mostly diachronously across European shelves (e.g., van de Schootbrugge et al., 2005; Wignall et al., 2005) and thus were not intimately implicated in the mass extinction (Gómez et al., 2008; Gómez and Goy, 2011). Similarly, the negative CIE has only been observed in a few well dated and continuous sections outside Europe (Bodin et al., 2010; Caruthers et al., 2011) and is absent in belemnite $\delta^{13} \mathrm{C}$ records of the T-OAE, thereby casting doubt on the global expression of the isotopic perturbations (Wignall et al., 2005; van de Schootbrugge et al., 2005). On the other hand, belemnites are extremely scarce during the crucial interval (van de Schootbrugge et al., 2005; Hesselbo et al., 2007; Gómez et al., 2008) and hence may not fully record the details of seawater carbon isotope fluctuations across the T-OAE (Hesselbo et al., 2007).

A negative CIE has been recently reported in two different marine Toarcian successions from Argentina (Al-Suwaidi et al., 2010; Mazzini et al., 2010), providing the first southern hemisphere records of the event and substantiating the global significance of the carbon cycle perturbation. Nevertheless, a comprehensive appraisal of the expression of the T-OAE in Argentina is precluded by a major hiatus in the section studied by Al-Suwaidi et al. (2010) and the lack of zonal level ammonite biostratigraphical control in that of Mazzini et al. (2010). Moreover, the relationships between the CIE, the onset of black shale deposition and the extinction event have only been documented in low latitude NW European sections (e.g., Wignall et al., 2005; Caswell et al., 2009), resulting in large uncertainties concerning the timing between biotic loss, decreased seawater oxygenation and changes in carbon cycling at a global scale. 
We present new lithological and geochemical data generated from three high latitude marginal marine sections exposed in N Siberia to reconstruct the sea level, carbon cycling and redox history from the Late Pliensbachian to the Late Toarcian in Arctic basins. The ages of the sections are well-constrained based on ammonite, bivalve, dinoflagellate cyst and foraminiferal species that are well correlated to the standard European ammonite zones (Figs. 1,2A). The new data allow the deciphering of regional and global aspects of environmental changes associated with the T-OAE as well as addressing important questions about climate and biotic changes in the Arctic regions throughout this key interval.

\section{Depositional setting and biostratigraphy}

\subsection{Lithostratigraphy}

The Anabar Bay, Kelimyar River and Polovinnaya River localities expose PliensbachianToarcian marine successions of sandstone, siltstone and mudstone that were deposited near the Early Jurassic North Pole (Fig. 1). The successions studied at Anabar Bay and Kelimyar River correspond, respectively, to sections 11-12 and 16 of Knyazev et al. (2003). The lower parts of the measured sections at Anabar Bay and Polovinnaya River (Airkat Formation; Fig. 1C) consist of interbedded sandstone, siltstone and silty clay of latest Pliensbachian age, locally rich in large glendonites $(\varnothing>5 \mathrm{~cm})$ at Anabar Bay (Figs. 1, 2B). Equivalent levels at Kelimyar River (Kyra Formation; Fig. 2B) are represented by a succession of siltstone and sandy siltstone with occasional, exotic boulder-sized clasts (composed of limestone, marly limestone and basalts) that are frequently encrusted by bivalves (Figs. 2B, 3). Similar, pebble to boulder-sized exotic clasts were commonly observed throughout the upper $25 \mathrm{~m}$ of the Kyra Formation in all nearby successions of the Olenek-Kelimyar Rivers (Devyatov et al., 2010). At Polovinnaya River, the presence of abundant macroscopic wood pieces and $2-3 \mathrm{~cm}$ pebbles above the wavy and oxidized unconformity between the sandstone beds of Beds 1 and 2 indicate that emersion and subaerial erosion were likely to have occurred at this level (Fig. 2B). This, together with the overall coarser nature of the exposed sediments compared to Anabar Bay and Kelimyar River, point to shallowest depositional conditions at Polovinnaya River. By contrast, the overall finer nature of the sediments at Kelimyar River as compared to the two other sections suggests deposition under substantially deeper conditions or at greater distance from major sediment source areas (Fig. 2B). However, a major hiatus is recorded at 
134 the Pliensbachian-Toarcian transition in coeval sections near the Kelimyar River section

135 (Olenek-Kelimyar Rivers), implying that the depositional depth in the area was sufficiently

136 low to enable subaerial erosion/non deposition during the sea-level fall (Fig. 2B). These

137 lithological trends indicate that the Polovinnaya River, Anabar Bay and Kelimyar River

138 successions were deposited in shallow, intermediate and deep continental shelf environments

139 respectively.

140 The overlying Kiterbyut Formation at Polovinnaya River and Anabar Bay comprises dark

141 grey mudstone likely deposited at much greater depths than the underlying sandstone and

142 siltstone, thus signifying substantial sea-level rise. Sediment starvation and accelerated rates

143 of sea-level rise are indicated by high concentrations of belemnite rostra at $\sim 0.20 \mathrm{~m}$ and $\sim 9$

$144 \mathrm{~m}$ at Polovinnaya River and $2.5 \mathrm{~m}$ at Anabar Bay (Fig. 2B). Coeval beds of the Kurung

145 Member at Kelimyar River comprise finely laminated, black to brownish shale with large

146 calcareous concretions in the lowermost part of the section. The upper parts of the Anabar

147 Bay (Eren Formation) and Kelimyar River (Kelimyar Formation) sections comprise a

148 succession of siltstone and sandstone that indicate a return to shallower conditions. The

149 macrofauna at Polovinnaya River and Anabar Bay is represented by abundant thin-shelled

150 bivalves, fish debris, corroded and partly silicified belemnite rostra and poorly preserved

151 ammonites. The Kelimyar River section yielded several well-preserved, identifiable

152 ammonites, brachiopods, bivalves and abundant belemnite rostra.

\subsection{Biostratigraphy}

The biostratigraphical framework of the sections investigated is based on ammonites, dinoflagellate cysts, benthic foraminifera and bivalves. Polovinnaya River samples were also investigated for calcareous nannofossils but no identifiable specimens were recovered. The ammonite biostratigraphy of the Kelimyar River section is relatively well constrained due to

160 the occurrence of a number of key diagnostic species at several horizons (Fig. 2A, B).

161 Additional biostratigraphical resolution was obtained from recent investigations of

162 foraminifera and dinoflagellate cysts developed for the Pliensbachian-Toarcian sections near

163 the Kelimyar and Olenek Rivers and from coeval ammonite-rich sections (Knyazev et al., 164 2003; Nikitenko, 2008, 2009) of northeast Russia (Astronomicheskaya and Saturn Rivers)

165 (Fig. 1B). According to biostratigraphical schemes developed for NE Russia (Nikitenko, 166 2009), the JF9a-JF9b foraminifera zone boundary identified at $0 \mathrm{~m}$ corresponds to the 167 Pliensbachian-Toarcian boundary (viligaensis-antiquum ammonite zones) while the JF9a- 
JF11 boundary identified at $0.12 \mathrm{~m}$ corresponds to the antiquum-falciferum boundary. Recent collecting in nearby coeval successions (Fig. 2A) indicates that the first occurrence (FO) of the ammonite Dactylioceras commune approximates to that of the dinoflagellate cyst Nannoceratopsis gracilis (NSJ2), while the FO of the ammonite Pseudolioceras compactile (Late Toarcian) coincides with that of the dinoflagellate cysts Valvaeodinium aquilonium and Nannoceratopsis triangulata (NSJ3b). Accordingly, the respective bases of the commune and compactile zones at Kelimyar River can be confidently placed at $3.9 \mathrm{~m}$ and $11.8 \mathrm{~m}$ (Fig. 2B).

Due to the absence of identifiable ammonites in the interval studied at Anabar Bay and Polovinnaya River, the biostratigraphy of these sections is based on dinoflagellate cysts, benthic foraminifera and bivalves (Fig. 2A) (Zakharov et al., 1997; Riding et al., 1999; Nikitenko and Mickey, 2004; Nikitenko, 2008, 2009). The presence of foraminifera diagnostic of the JF8 and JF9a zones (Nikitenko, 2009) in the sandstone and siltstones of the Airkat Formation at Anabar Bay indicates that the measured interval of the Airkat Formation is of Late Pliensbachian age (margaritatus-viligaensis zones). Occurrences of the bivalves of the Tancredia kuznetsovi bivalve subzone further suggest that this interval is the time equivalent of the viligaensis zone (Shurygin, 2005). The absence of diagnostic foraminifera of the JF9b zone indicates that the interval corresponding to the antiquum ammonite zone is probably entirely missing in both sections. The placement of the base of the Lower Toarcian in both sections relies on the occurrences of foraminifera diagnostic of the JF11 zone and the bivalve Dacryomya inflata (Knyazev et al., 2003; Nikitenko and Mickey, 2004). At Polovinnaya River, the interval above $\sim 9 \mathrm{~m}$ yielded only non-diagnostic foraminifera. The dinoflagellate cyst Nannoceratopsis gracilis was not observed in the entire section, however questionable specimens of Valvaeodinium aquilonium occur at $13.5 \mathrm{~m}$, suggesting that the upper part of the Polovinnaya River section could be of latest Early Toarcian-Late Toarcian age (Fig. 2A, B). Hence, the NSJ2 zone may be entirely missing at Polovinnaya River, implying the presence of a major hiatus above $9 \mathrm{~m}$ (Fig. 2B).

\section{Material and methods}

\subsection{Organic geochemistry}

Decarbonated and oven-dried sediment samples were analyzed for Total Organic Carbon content (TOC in wt.\%) and their stable carbon isotope composition $\left(\delta^{13} \mathrm{C}_{\mathrm{TOC}}\right)$ with an Eurovector Elemental Analyzer (EuroEA3028-HT) connected to a GV instrument Isoprime 
isotope ratio mass spectrometer at the University of Lyon 1 (Polovinnaya River samples) and with a Carlo Erba 1108 elemental analyzer connected to a Finnigan Delta V isotope ratio mass spectrometer at the University of Lausanne (Anabar Bay and Kelimyar River samples). The stable carbon isotope ratios are reported in the delta notation as the per mil (\%o) deviation relative to the Vienna Peedee belemnite (VPDB) standard: $\delta=\left(\mathrm{R}_{\text {sample }}-\mathrm{R}_{\text {standard }}\right) / \mathrm{R}_{\text {standard }} \mathrm{X}$ 1000 with $\mathrm{R}={ }^{13} \mathrm{C} /{ }^{12} \mathrm{C}$. Analytical precision and accuracy were determined by replicate analyses and by comparison with international and in-house standards (IAEA CH7 and tyrosine at the University of Lyon 1; USGS 24, UREA, glycine and pyridine at the University of Lausanne), and were better than $0.1 \mathrm{wt} . \%(1 \sigma)$ and $0.1 \%$ o $(1 \sigma)$ for TOC and $\delta^{13} \mathrm{C}_{\mathrm{TOC}}$, respectively.

\subsection{Rock-Eval pyrolysis}

$$
\text { Information on the type and thermal maturity of the bulk organic matter was obtained by }
$$
Rock-Eval pyrolysis using a RE 6 Turbo device at the University Paris 6 (Polovinnaya River samples) and RE 6 device at the University of Lausanne (Kelimyar River samples) under standard conditions (Béhar et al., 2001). The Hydrogen Index (HI, mg HC/g TOC), Oxygen Index (OI, $\mathrm{mg} \mathrm{CO}_{2} / \mathrm{g}$ TOC), $\operatorname{Tmax}\left({ }^{\circ} \mathrm{C}\right)$ and TOC (wt.\%) were determined. Analytical precision was better than $0.05 \mathrm{wt} . \%(1 \sigma)$ for TOC, $1.5^{\circ} \mathrm{C}(1 \sigma)$ for Tmax, $10 \mathrm{mg} \mathrm{HC} / \mathrm{g}$ TOC $(1 \sigma)$ for $\mathrm{HI}$ and $10 \mathrm{mg} \mathrm{CO}_{2} / \mathrm{g}$ TOC $(1 \sigma)$ for OI. The TOC contents measured by Rock-Eval pyrolysis were in excellent agreement with those measured during the $\delta^{13} \mathrm{C}_{\mathrm{TOC}}$ acquisition, with correlation coefficients $\left(\mathrm{R}^{2}\right)$ of 0.8 for Polovinnaya River samples and 0.97 for Kelimyar River samples.

\subsection{Pyrite framboid measurements}

Smear slides for pyrite framboid measurements were prepared by gentle mechanical breakage of a small amount of rock, dilution with water, spreading onto a coverslip and drying in a stove. The maximum diameter of pyrite framboids from Polovinnaya River was measured on images acquired by light microscopy with a CCD camera (Sony XC-77CE mounted on a polarizing microscope ZEISS Axioscope 40). For each horizon, 30 framboids were measured by means of the software Scion Image (beta version 402) with an estimated error of $\pm 0.17 \mu \mathrm{m}$. Fragmented pyrite framboids were not observed while non-framboidal 
particles exceeding $50 \mu \mathrm{m}$ were commonly observed during the measurements, indicating that the mechanical breakage did not affect the size distribution of the measured framboids.

\section{Results}

\subsection{Organic stable carbon isotope and total organic carbon data}

The $\delta^{13} \mathrm{C}_{\mathrm{TOC}}$ and TOC data from the three sections investigated reveal comparable trends (Fig. 4). The deeper and more complete Kelimyar River section exhibits a pronounced 6\% negative CIE starting at the boundary of the antiquum-falciferum ammonite zones above a major flooding surface and reaching minimum values $(-32 \%)$ in the lowermost part of the falciferum zone (Fig. 4). Similar trends occur at Anabar Bay and Polovinnaya River, although the CIE is proportionally reduced and profoundly negative $\delta^{13} \mathrm{C}_{\mathrm{TOC}}$ values $(<-30 \%)$ are absent (Fig. 4). In all three sections, the decrease in $\delta^{13} \mathrm{C}_{\mathrm{TOC}}$ at the base of the falciferum zone is accompanied by a marked rise in TOC contents. The succeeding interval (falciferumcommune zones) at Anabar Bay and Kelimyar River records high TOC, and a corresponding plateau of relatively negative $\delta^{13} \mathrm{C}_{\mathrm{TOC}}$ values. The record at Kelimyar River indicates that the end of black shale deposition, and a return to almost pre-excursion values, occurred in the middle of the commune zone (Fig. 4). The abrupt $\sim 2 \%$ shift to lighter values recorded at $\sim 9 \mathrm{~m}$ at Polovinnaya River is accompanied by elevated belemnite concentrations (Figs. 2, 4) and most likely reflect a major break in sedimentation. Biostratigraphical data (see part 2.2.) indicate that this shift and the following interval of rather low $\delta^{13} \mathrm{C}_{\mathrm{TOC}}$ values most likely correlate with the $\sim 2 \%$ negative CIE recorded across the Lower-Upper Toarcian transition at Kelimyar River (from $\sim 8$ to $\sim 15$ m; Fig. 4 ).

\subsection{Organic matter sourcing}

The crossplots of HI/OI values indicate that the organic matter (OM) mainly consists of hydrogen-poor terrestrial material and altered organic matter (Type III/IV kerogen) in the Polovinnaya River section and of a mixture of terrestrial and marine material (Type II/III kerogen) in the Kelimyar River section (Fig. 5). This observation is consistent with the more proximal depositional setting inferred for the Polovinnaya River site. At both sites, HI values increase across the Pliensbachian-Toarcian boundary, indicating increased contribution of 
marine material during transgression (Fig. 4). At Kelimyar River, lowest $\delta^{13} \mathrm{C}_{\mathrm{TOC}}$ values recorded across the antiquum-falciferum boundary correspond to low HI values (30-100 mg $\mathrm{HC} / \mathrm{gTOC})$. Importantly, the most ${ }^{13} \mathrm{C}$-depleted sample $\left(\delta^{13} \mathrm{C}_{\mathrm{TOC}}=-32 \%\right.$ ) has a TOC of 3.5 wt.\%, indicating that its low HI value is unlikely to be the result of intense OM oxidation but most probably reflects a terrestrial-derived OM source (Fig. 4). Highest HI values occur at $\sim 5$ $\mathrm{m}$ and decrease significantly in the upper part of the black shale interval and overlying silty beds (commune zone), indicating decreased marine OM sourcing (Fig. 4).

\subsection{Oxygenation}

At all sites, strong oxygen-depletion throughout the interval of high TOC values (falciferum-basal commune zones; Figs. 2, 4) is indicated by distinct lamination, the sporadic occurrence of monospecific associations of thin-shelled bivalves and thin-valved ostracodes typical of oxygen-poor environments (Nikitenko and Mickey, 2004; Zakharov et al., 2006) and the absence of both endobenthic fauna and bioturbation. The mean size of the pyrite framboids recorded through the falciferum and commune zones at Polovinnaya River (Fig. 4) are lower than $7 \mu \mathrm{m}$, consistent with nucleation and growth within a strongly dysaerobic to possibly euxinic environment (Wilkin et al., 1996; Wignall and Newton, 1998). The framboid size distribution indicates that even shallow marine areas became strongly oxygen-depleted at this time. However, lower TOC contents and higher abundance of monospecific thin-shelled bivalves at Polovinnaya River indicate longer or more frequent oxygenation events at shallower sites.

\section{Discussion}

\subsection{Origin of the negative carbon isotope excursion}

The high-resolution biostratigraphical control of our new geochemical data from N Siberia allows a direct comparison with previous records for the T-OAE in order to decipher the global and regional aspects of the event. A marked increase of HI values, likely reflecting increased marine OM preservation or input, has been documented across the onset of the CIE in most records from Europe (e.g., Baudin et al., 1990; Prauss et al., 1991; Röhl et al., 2001;

302 Sabatino et al., 2009). The Kelimyar River record, corresponding to the most complete of the 
three investigated N Siberian sections, indeed reveals an overall increase of HI values across the $\mathrm{CIE}$ and thus indicates increased marine OM input during the accompanying transgression (Fig. 4). Because Toarcian marine OM appears to have been more ${ }^{13} \mathrm{C}$-depleted than terrestrial OM (Hesselbo et al., 2000), the CIE recorded by bulk OM in N Siberia could conceivably reflect changes in the OM sourcing. However, lowest $\delta^{13} \mathrm{C}_{\mathrm{TOC}}$ values $(<-29 \%)$ recorded across the antiquum-falciferum zone transition correspond to low HI values characteristic of terrestrial OM (32 to $100 \mathrm{mgHC} / \mathrm{gTOC}$; Fig. 4), thus ruling out increased marine OM contribution as the main cause of the marked $\delta^{13} \mathrm{C}_{\mathrm{TOC}}$ shift towards lower values at this site. Similarly, the relatively low HI (3 to $91 \mathrm{mgHC} / \mathrm{gTOC}$ ) values from Polovinnaya River correlate poorly with $\delta^{13} \mathrm{C}_{\text {TOC }}$ (Fig. 4), indicating little influence of the type of preserved OM on the recorded isotopic fluctuations. In this regard, the absence of very negative $\delta^{13} \mathrm{C}_{\mathrm{TOC}}$ values $(<-30 \%)$ at the base of the falciferum zone at Polovinnaya River and Anabar Bay might point to a substantial lateral variability of the $\delta^{13} \mathrm{C}_{\mathrm{TOC}}$ signal (Fig. 4). In both sections, however, the marked $\delta^{13} \mathrm{C}_{\mathrm{TOC}}$ shift towards lower values occurs in an interval characterized by elevated belemnite concentrations above a major flooding surface; given the relatively coarse resolution of our sampling (every $0.25 \mathrm{~m}$ at Polovinnaya River and $0.5 \mathrm{~m}$ at Anabar Bay), the absence of very negative $\delta^{13} \mathrm{C}_{\mathrm{TOC}}$ values at both sites can more likely be attributed to extremely reduced sedimentation rates or even to non-deposition due to transgression-induced sediment starvation. Importantly, comparison of the biostratigraphically well-constrained succession of Kelimyar River with that of SW Germany (where coeval TOC, HI and $\delta^{13} \mathrm{C}_{\mathrm{TOC}}$ records are available at sufficiently high resolution) reveals almost identical temporal $\delta^{13} \mathrm{C}_{\mathrm{TOC}}$ trends while their HI profiles differ considerably (Fig. 6). These observations show that the type of preserved OM has little influence on the recorded isotopic profiles and support the inference that the CIE is not compositionally controlled, as suggested independently by compound-specific $\delta^{13} \mathrm{C}$ data from SW Germany (Schouten et al., 2000).

It has been repeatedly proposed that the CIE reflects regional upwelling of mineralized ${ }^{13}$ C-depleted carbon in salinity-stratified restricted basins (Küspert, 1982; Schouten et al., 2000; van de Schootbrugge et al., 2005; McArthur et al., 2008). In this case, the amount of ${ }^{13} \mathrm{C}$-depleted carbon recycling would logically have been a function of the extent of stratification and associated amount of available degradable OM and a systematic relationship between the amount of TOC and the magnitude of the CIE should be expected. The TOC and $\delta^{13} \mathrm{C}_{\mathrm{TOC}}$ records from Anabar Bay indeed show a good correlation (Fig. 5), pointing to a possible link between the recycling of ${ }^{13} \mathrm{C}$-depleted carbon and general $\delta^{13} \mathrm{C}_{\text {TOC }}$ trends. The 
Kelimyar River (Fig. 5), suggesting a less pronounced overprinting of the $\delta^{13} \mathrm{C}_{\mathrm{TOC}}$ values by local ${ }^{13} \mathrm{C}$-depleted carbon recycling at these localities. In this regard, it is noteworthy that the TOC-rich interval is about half as thick and the TOC contents approximately half lower in the most complete Kelimyar River section than in SW Germany (Fig. 6), implying that the amount of carbon buried per unit of time was at least four times lower in N Siberia than in SW Germany (Fig. 6). Notwithstanding these substantially different rates of carbon burial, both successions record almost identical $\delta^{13} \mathrm{C}_{\text {TOC }}$ values and trends (Fig. 6). Consistent with previous compound-specific and biomarker data from France (van Breugel et al., 2006), this comparison suggests that the magnitude and shape of the CIE cannot be entirely explained by the degree of stratification of these basins. Our new N Siberian data indicate that the upwelling of the mineralized ${ }^{13} \mathrm{C}$-depleted carbon and changes in $\mathrm{OM}$ sourcing, although possibly exerting an influence on general $\delta^{13} \mathrm{C}_{\mathrm{TOC}}$ records, were unlikely to be the main causes of the CIE, and thus support the idea that the CIE reflects a rapid and synchronous injection of ${ }^{13} \mathrm{C}$-depleted carbon to all exchangeable reservoirs (e.g., Hesselbo et al., 2000, 2007; Kemp et al., 2005; Cohen et al., 2007; Hesselbo and Pieńkowski, 2011; Caruthers et al., 2011). Accordingly and provided that the source of the analyzed carbon and the biostratigraphy are sufficiently well constrained, the CIE might constitute a valuable chemostratigraphic marker between distant sites, with a resolution potentially far higher than that available from ammonite or nannofossil biostratigraphy.

\subsection{Climatic conditions across the T-OAE in the polar regions}

Different sedimentological indicators point to cold climate conditions in the Arctic prior to the T-OAE negative CIE and accompanying onset of oxygen-depletion. Cold bottom water temperatures during the Late Pliensbachian are indicated by the occurrence of large $(\varnothing>5 \mathrm{~cm})$ glendonites (calcite pseudomorphs after ikaite) in Upper Pliensbachian strata at Anabar Bay (Figs. 2, 3) and several other localities in N Siberia (Kaplan, 1978). Indeed, ikaite precipitation in the sediment at the seafloor might be favored by several factors (e.g., high alkalinity, elevated phosphate concentrations), among which temperatures lower than $4^{\circ} \mathrm{C}$ appear as the most significant, making glendonites robust indicators of cold water conditions (e.g., Bischoff et al., 1993; Selleck et al., 2007). As such, the absence of glendonites in Upper Pliensbachian strata of Polovinnaya River and Kelimyar River suggests that the conditions favoring ikaite precipitation or its subsequent transformation into pseudomorphic calcite may have only been met in specific areas. The glendonites of Anabar Bay occur in sediments 
deposited at very shallow depths and were thus most likely formed at or above the thermocline, suggesting that sea surface temperatures were at least locally no more than a few degrees higher than the formation temperature of ikaite during this interval. Low sea surface temperatures are consistent with the occurrence of isolated, likely ice-rafted boulders encrusted by Harpax bivalves within otherwise homogenous coeval siltstone succession at Kelimyar River and in nearby areas (Figs. 2, 3; see also part 2.1.). It has been argued that deposition of similar isolated exotic boulders may have resulted from driftwood rafting and may not necessarily indicate ice transport (Bennett and Doyle, 1996). In this case, boulders transported by driftwood should then also be observed in low latitude epicontinental marine areas surrounded by the large landmasses of the $\mathrm{N}$ Tethyan margin, where trees would have been relatively common and the occurrence of driftwood is well documented (e.g., Hesselbo et al., 2007). To our knowledge, however, no such erratic boulders have been reported from contemporaneous European successions, and this despite abundant lithological descriptions of epicontinental Upper Pliensbachian strata (e.g., Howarth, 1985; Hesselbo and Jenkyns, 1995; Suan et al., 2010; van de Schootbrugge et al., 2010). Whilst a driftwood origin cannot be totally excluded, ice transport appears as a more parsimonious explanation given the polar paleolatitude of the sites studied (Fig. 1); the lack of evidence of transport by continental ice such as striation or faceting suggests that these boulders reflect the at least intermittent (possibly seasonal) formation of polar sea ice at this time.

Evidence for considerable warming at the antiquum-falciferum zone transition is the disappearance of glendonites and exotic boulder-sized clasts and the appearance of low latitude terrestrial plant taxa throughout the Arctic region, including abundant proportions of the thermophyllic (e.g., Traverse, 2007) pollen genus Classopollis (Vakhrameev, 1991; Zakharov et al., 2006). Reports of plants of subtropical to tropical affinities (Ptilophyllum) in central and NE Siberia additionally suggest an interval of extreme polar to subpolar warmth during the succeeding falciferum-early commune interval (Vakhrameev, 1991). Indications of unusually warm and humid conditions at slightly lower latitudes also come from reports of weathering crusts of kaolinite and bauxite in Lower Toarcian continental deposits of the W Siberian Basin (Fig. 1; Kontorovich et al., 1997), but these clearly need further documentation and biostratigraphical analyses. The disappearance of abundant Classopollis and associated thermophyllic plant elements from the Arctic in the middle part of the commune zone (Zakharov et al., 2006) indicates that the termination of black shale deposition probably coincided with a return to substantially cooler conditions (Fig. 6). These sedimentological and 
the T-OAE negative CIE in Arctic areas and indicate that exceptionally warm climate conditions persisted during the following interval of poor marine oxygenation (see part 5.4.).

\subsection{Sea level changes}

The lithological successions of the three sections studied point to significant changes in sea level across the Pliensbachian-Toarcian interval in the Arctic Basin. In all sections, the Upper Pliensbachian is dominated by sandy and silty lithologies suggestive of very shallow depositional conditions, while the Lower Toarcian is dominated by clay lithologies clearly deposited at greater water depths. The major unconformity recorded immediately below the $\mathrm{CIE}$ at the Pliensbachian-Toarcian transition in Anabar Bay and Polovinnaya River sections (Fig. 2) has been documented in the entire Arctic region, and was probably linked to a shortlived episode of subaerial exposure (Nikitenko and Mickey, 2004; Zakharov et al., 2006). Importantly, this unconformity is overlain by fine clay in Anabar Bay and Polovinnaya River sections, suggesting that the sea level rose markedly and relatively rapidly across the CIE. It should be noted that a similar history of sea-level changes has been inferred from coeval foraminifera and ostracode assemblages from the entire Arctic region (Nikitenko, 2009), thus ruling out changing sediment supply as the main cause of these lithological changes.

Significantly, the condensed lowermost part of the CIE in shallow marine sites of $\mathrm{N}$ Siberia is strikingly similar to that recorded in tropical shallow marine sites (van Breugel et al., 2006) (Fig. 7). As observed in N Siberia, the earliest Toarcian ammonite zone (the tenuicostatum zone) is also frequently reduced or even absent in NW Europe, so that T-OAE organic-rich sediments often unconformably rest on Upper Pliensbachian strata in several sections in England (Wignall, 1991), S France (Guex et al., 2001; Léonide et al., in press) and Germany (Röhl and Schmid-Röhl, 2005). These observations indicate synchronicity of sea level changes in distant $(>5,000 \mathrm{~km})$ areas and indicate that the massive ${ }^{13} \mathrm{C}$-depleted carbon injection at the antiquum-falciferum zone transition coincided with a dramatic eustatic sea level rise following a major generalized regression. The short duration (80-150 kyr) of the $\delta^{13} \mathrm{C}_{\mathrm{TOC}}$ decrease (Kemp et al., 2005; Cohen et al., 2007; Suan et al., 2008; Sabatino et al., 2009) additionally suggests that the transgression was extremely rapid and hence most likely to have been climate-driven. The study of European sections with slightly different lithologies suggests that sea level rose by about 30-90 m between the deposition of uppermost Pliensbachian shallow-water sediments and that of organic-rich mudstones recording the CIE (Hallam, 1997). The $6-10^{\circ} \mathrm{C}$ warming recorded across the T-OAE (Bailey et al., 2003; 
Gómez et al., 2008; Suan et al., 2010), through thermal expansion (Revelle, 1990), may explain a 3-10 m sea-level rise, suggesting that several meters of sea level rise may have been related to the massive melting of continental ice. This latter explanation is compatible with evidence for near-freezing conditions in the pre-CIE interval of the sections studied (see part 5.2.; Fig. 4), and rapid cooling and widespread sea level fall during the Late Pliensbachianearliest Toarcian (Guex et al., 2001; Suan et al., 2010). Additionally, compelling evidence for rapid and large, probably glacially induced sea level fluctuations immediately prior to the TOAE lies in the identification of a series of incised valleys ranging from 20 to $50 \mathrm{~m}$ in depth within Upper Pliensbachian (margaritatus and spinatum zones) and lowermost Toarcian (intra tenuicostatum zone) offshore marine sediments from the North Sea (Marjanac and Steel, 1997). In this context, records of abundant and diverse Pliensbachian pollen and spore assemblages, and the lack of coeval voluminous glacial deposits (Zakharov et al., 2006), suggest that continental areas close to the North Pole remained largely ice-free during the entire Pliensbachian-Toarcian interval. Accordingly, any substantially large, pre-T-OAE icecap would most probably have been located in the high-latitude large landmasses of the southern hemisphere.

\subsection{Timing and causes of oxygen depletion during the T-OAE}

The association between the $6 \%$ negative CIE and the marked TOC rise at the antiquumfalciferum zone transition recorded in the more complete Kelimyar River section coincides precisely with that recorded at the tenuicostatum-falciferum zone transition or their equivalents in several low-latitude sites (Küspert, 1982; Hesselbo et al., 2000; Röhl et al., 2001; Prauss et al., 1991; van Breugel et al., 2006) (Figs. 6, 7). A similar succession of environmental change was recently reported in Argentina, although a hiatus prevents appraisal of post-CIE conditions in the section studied (Al-Suwaidi et al., 2010). In the Arctic, the interval recording high TOC values and decreased oxygenation is considerably expanded compared to that recording the negative CIE (Figs. 3, 6). A strikingly similar pattern is also present in many epicontinental sections from NW Europe (Fig. 7; Küspert, 1982; Röhl et al., 2001; McArthur et al., 2008; van Breugel et al., 2006), thus signifying stressful environmental perturbation for some considerable time after the end of the CIE. In more open marine records from S Europe, however, high TOC and evidence for poor oxygenation appear to be generally restricted to the CIE (Fig. 7; Parisi et al., 1996; Mattioli et al., 2004; Sabatino et al., 2009; Kafousia et al., 2011). Assuming that the CIE represents a 
good time marker (Hesselbo et al., 2007; Hesselbo and Pieńkowski, 2011; Caruthers et al., 2011; see part 5.1.), our new records from N Siberia therefore imply that oxygen-depletion developed near synchronously in most considered areas but faded away later in areas close to the large northern emergent landmasses of N Siberia and NW Europe. In addition, we note that some biostratigraphically well-constrained Lower Toarcian sections from southern Europe are essentially devoid of black shales or evidence of strong oxygen-depletion (e.g., Hesselbo et al., 2007; Gómez and Goy, 2011). These observations, combined to our new Siberian data, therefore imply that strong oxygen-deficiency was a widespread response of epicontinental seas to Toarcian climate changes, but suggests that both its timing and intensity, as suggested for most other OAEs (e.g., Jenkyns, 2010), may have been locally strongly modulated by regional factors.

Interestingly, clay mineral assemblages and oxygen isotope compositions of different biogenic material (carbonate of belemnites and brachiopods, phosphate of fish apatite), along with $\mathrm{Mg} / \mathrm{Ca}$ ratios of belemnites, indicate that the maximum development of oxygendepletion during the early falciferum zone occurred at times of exceptionally warm and humid conditions (Fig. 5; Rosales et al., 2006; Dera et al., 2009; Suan et al., 2010; Dera et al., 2011). Accordingly, widespread development of seawater oxygen-depletion in both polar and subtropical marginal shelves during the early falciferum zone interval likely resulted from density stratification and increased productivity due to an accelerated hydrological cycle under warm climate and elevated $\mathrm{CO}_{2}$ concentrations (e.g., Cohen et al., 2007; Dera et al., 2009; Jenkyns, 2010). In this regard, evidence for cold, possibly near-freezing conditions before the T-OAE in the Arctic is equally very significant because it supports the view that Arctic shelves were major sites of oxygen-rich, cold and deep water formation during at least parts of the Early Jurassic (Wignall et al., 2010). If correct, reduced pole-to-equator thermal gradients and increased freshwater runoff in Arctic regions during the early falciferum zone were likely to have decreased or shut down this formation of oxygen-rich deep waters, and could then have further contributed to oxygen-depletion in more open-ocean settings during peak warmth. Because seawater anoxia in open ocean settings may also result from elevated nutrient loads (Meyer and Kump, 2008), further modeling is required to constrain the respective role of changes in nutrient inputs, high-latitude oxygen solubility and polar deep water formation on global oceanic oxygenation during the T-OAE.

Clay mineral assemblages, oxygen isotope and $\mathrm{Mg} / \mathrm{Ca}$ ratios show that humidity and seawater temperatures decreased substantially during the following falciferum-bifrons zones, though not returning to pre-CIE conditions (Fig. 6; see Dera et al., 2009 and references 
therein). As global temperatures and weathering rates decreased during the falciferum zone

508 (Fig. 6), seawater oxygen-depletion probably gradually decreased in areal extent and became restricted to more sensitive areas close to large landmasses (i.e., the Arctic and the N Tethyan margin). At both polar and subtropical latitudes, the thickness of the interval showing evidence of poor oxygenation and high TOC is approximately twice that of the negative CIE

512 (Fig. 5). The duration of the CIE has been estimated at between $\sim 300$ and $\sim 900 \mathrm{ky}$ (Kemp et 513 al., 2005; Cohen et al., 2007; Suan et al., 2008). Assuming constant sedimentation rates for 514 the black shale intervals at Kelimyar River and in southwest Germany (Fig. 6), elevated 515 carbon burial and high temperatures thus persisted between 600 and 1,800 ky after the end of the CIE. If temperatures were $\mathrm{CO}_{2}$-forced during this interval (Fig. 6), this implies that widespread elevated carbon burial in marine realms was largely overcompensated by additional $\mathrm{CO}_{2}$ input. Such massive and long-lived carbon injection appears unlikely to have been caused solely by gas hydrate dissociation, but is instead compatible with the known protracted ( $>3 \mathrm{My}$ ) range of activity of the Karoo-Ferrar large igneous province (e.g., Jourdan et al., 2008).

\subsection{Timing and causes of biotic turnover}

Previous studies of fossil range data from the Arctic documented two main extinction horizons of different magnitude across the Pliensbachian-Toarcian interval (Nikitenko and Mickey, 2004; Zakharov et al., 2006; Nikitenko, 2008). A first extinction horizon was documented among several marine groups across the viligaensis-antiquum zone transition of NE Russia (Zakharov et al., 2006), which might correlate with that recorded at the Pliensbachian-Toarcian transition in Europe (Wignall et al., 2005; Caswell et al., 2009). However, the reduced thickness or absence of this interval in the sites studied herein hampers appraisal of the accompanying environmental changes in the Arctic. A second extinction horizon of higher magnitude, involving a complete reorganization of bivalve, ostracode, benthic foraminifera, pollen and spore assemblages has been previously identified over the entire Arctic basin at the antiquum-falciferum zone transition (Nikitenko and Mickey, 2004; Zakharov et al., 2006; Nikitenko, 2008), and hence correlates with the prominent $\delta^{13} \mathrm{C}_{\mathrm{TOC}}$ fall the base of the CIE in our more complete Kelimyar River record (Fig. 6). In low latitude sites, macrofossil and microfossil data place the main marine extinction horizon slightly below or within the $\delta^{13} \mathrm{C}_{\mathrm{TOC}}$ fall (Wignall et al., 2005; Boomer et al., 2008; Caswell et al., 2009; Gómez and Goy, 2011). 
Assuming that the CIE does reflect a synchronous and global event (see part 5.1.), the main extinction episode thus appears to have been broadly synchronous between Arctic and low latitude sites (Fig. 6). The close association between the extinctions and the $\delta^{13} \mathrm{C}_{\mathrm{TOC}}$ fall in both regions suggests that biotic losses may have been caused by environmental changes directly ensuing from massive ${ }^{13} \mathrm{C}$-depleted carbon injection. Nevertheless, macrofossil range data from the well-studied sections of the Yorkshire coast place the extinction horizon of many invertebrates slightly below the $\delta^{13} \mathrm{C}_{\mathrm{TOC}}$ fall in the upper tenuicostatum zone, suggesting that some biotic losses predated the CIE and were thus unrelated to the ${ }^{13} \mathrm{C}$ depleted carbon injection (Wignall et al., 2005; Caswell et al., 2009). Unfortunately, the resolution of our sampling of the stratigraphically very reduced antiquum zone in Kelimyar River is too coarse to investigate the detailed stratigraphic relationships between the CIE and extinctions, while the Arctic sections from NE Russia characterized by an expanded antiquum-falciferum zone transition (where the details of the extinctions could be potentially best seen) currently lack $\delta^{13} \mathrm{C}$ records and have relatively low resolution biotic records (e.g., Knyazev et al., 2003; Nikitenko and Mickey, 2004). Further detailed geochemical and paleontological investigations are thus needed to better constrain the precise timing, and hence cause-and-effects relationships, between carbon injection and biotic turnover in both high- and low-latitude areas during this crucial interval.

\section{Conclusions}

An abrupt 6\% negative CIE is revealed in bulk organic carbon during the onset of the TOAE from biostratigraphically well constrained marine sections deposited at polar paleolatitudes. Rock Eval pyrolysis and comparisons with tropical paleolatitudes indicate that changing OM sources and basin restriction were very unlikely to be the main causes of the TOAE negative CIE and support the hypothesis that the isotopic anomaly reflects a massive and rapid injection of ${ }^{13} \mathrm{C}$-depleted carbon into ocean-atmosphere system. Lithological and paleontological data from the Arctic indicate that this injection coincided with changes from cold to exceptionally warm climate and the onset of marine oxygen deficiency. Evidence for near-freezing climate conditions in the Arctic before the T-OAE (i.e., exotic boulder-sized clasts and large glendonites) suggests that the rapid sea level rise recorded in both domain during the carbon injection was caused by a combination of thermal expansion of seawater and massive and rapid melting of continental ice. The persistence of warm climate and poorly 
oxygenated conditions more than $600 \mathrm{ky}$ after the CIE at both polar and tropical sites indicates prolonged carbon injection despite concomitant elevated redox-driven carbon burial, consistent with a massive and protracted input of volcanogenic carbon. The main phase of marine biota extinction appears to have been closely related with the onset of massive ${ }^{13} \mathrm{C}$ depleted carbon injection in both Arctic and low latitude sites, but further work is required to constrain cause-and-effects relationships between warming, massive carbon injection and perturbation of both marine and terrestrial ecosystems across the T-OAE.

\section{Acknowledgments}

We are grateful to F. Fourel and B. Bomou for laboratory assistance and to P. Wignall, B. Gill and anonymous reviewers for their helpful comments on earlier versions of this manuscript. This work was supported by RAS projects numbers 17 and 24, the CUS Geonova project and the Regional Geological and Geophysical Studies of the Siberian Arctic Continental Margin Project funded by TGS-NOPEC Geophysical Company. J.B.R. publishes with the approval of the Executive Director, British Geological Survey (NERC).

\section{References}

Al-Suwaidi, A.H., Angelozzi, G.N., Baudin, F., Damborenea, S.E., Hesselbo, S.P., Jenkyns, H.C., Manceñido, M.O., Riccardi, A.C., 2010. First record of the Early Toarcian Oceanic Anoxic Event from the Southern Hemisphere, Neuquén Basin, Argentina. J. Geol. Soc. London 167, 633-636.

Baudin F., Herbin, J-P., Vandenbroucke, M. 1990. Mapping and geochemical characterization of Toarcian organic matter in the Mediterranean Tethys. Organic Geochemistry 16, $677-687$.

Bailey, T.R., Rosenthal, Y., McArthur, J.M., van de Schootbrugge, B., Thirlwall, M.F., 2003. Paleoceanographic changes of the Late Pliensbachian-Early Toarcian interval: a possible link to the genesis of an Oceanic Anoxic Event. Earth Planet. Sci. Lett. 212, 307-320.

Béhar, F, Beaumont, V., De B. Penteado, H.L., 2001. Rock-Eval 6 Technology: Performances and Developments: Oil \& Gas Science and Technology. Revue de l'IFP 56, 111-134.

Bennett, M.R., Doyle, P., 1996. Global cooling inferred from dropstones in the Cretaceous: fact or wishful thinking? Terra Nova 8, 182-185.

Bilotta, M., Venturi, F., Sassaroli, S., 2010. Ammonite faunas, OAE and the PliensbachianToarcian boundary (Early Jurassic) in the Apennines. Lethaia 43, 357-380. 
Bischoff, J.L., Fitzpatrick, J.A., Rosenbauer, R.J., 1993. The solubility and stabilization of ikaite $(\mathrm{CaCO} 3-6 \mathrm{H} 2 \mathrm{O})$ from $0^{\circ}$ to $25^{\circ} \mathrm{C}$; environmental and paleoclimatic implications for thinolite tufa. J. Geol. 101, 21-33.

Bodin, S., Mattioli, E., Fröhlich, S., Marshall, J.D., Boutib, L., Lahsini, S., Redfern, J., 2010. Toarcian carbon isotope shifts and nutrient changes from the Northern margin of Gondwana (High Atlas, Morocco, Jurassic): palaeoenvironmental implications. Palaeogeogr. Palaeoclimatol. Palaeoecol. 297, 377-390.

Caruthers, A.H., Gröcke, D.R., Smith, P.L., 2011. The significance of an Early Jurassic (Toarcian) carbon-isotope excursion in Haida Gwaii (Queen Charlotte Islands), British Columbia, Canada. Earth Planet. Sci. Lett. 307, 19-26

Caswell, B.A., Coe, A.L., Cohen, A.S., 2009. New range data for marine invertebrate species across the early Toarcian (Early Jurassic) mass extinction. J. Geol. Soc. London 166, 859-872.

Cohen, A.S., Coe, A.L., Harding, S.M., Schwark L., 2004, Osmium isotope evidence for the regulation of atmospheric $\mathrm{CO}_{2}$ by continental weathering. Geology 32, 157-160.

Cohen, A.S., Coe, A.L., Kemp, D.B., 2007. The Late Palaeocene-Early Eocene and Toarcian (Early Jurassic) carbon isotope excursions: a comparison of their time scales, associated environmental changes, causes and consequences. J. Geol. Soc. London 164, 10931108.

Dera, G., Pellenard, P., Neige, P., Deconinck, J.-F., Pucéat, E., Dommergues, J.-L., 2009. Distribution of clay minerals in Early Jurassic Peritethyan seas: palaeoclimatic significance inferred from multiproxy comparisons. Palaeogeogr. Palaeoclimatol. Palaeoecol. 271, 39-51.

Dera, G., Brigaud, B., Monna, F., Laffont, R., Pucéat, E., Deconinck, J.-F., Pellenard, P., Joachimski, M.M., Durlet, C., 2011. Climatic ups and downs in disturbed Jurassic world, Geology 39, 215-218.

Devyatov, V.P., Knyazev, V.G., Nikitenko, B.L., Melnik, O.A., Glinskikh, L.A., 2010. Pliensbachian - Toarcian boundary of northeastern Siberia and startigraphic position of the Kurung Mbr of the Kelimyar Formation (Kelimyar River, Olenek River basin). Otechestvennaya geologiya 5, 105-112.

Gómez, J.J., Goy, A., 2011. Warming-driven mass extinction in the Early Toarcian (Early Jurassic) of northern and central Spain. Correlation with other time-equivalent European sections. Palaeogeogr. Palaeoclimatol. Palaeoecol. 306, 176-195 
Gómez, J.J., Goy, A., Canales, M.L., 2008. Seawater temperature and carbon isotope variations in belemnites linked to mass extinction during the Toarcian (Early Jurassic) in Central and Northern Spain. Comparison with other European sections. Palaeogeogr. Palaeoclimatol. Palaeoecol. 258, 28-58.

Gröcke, D.R., Rimmer, S.M., Yoksoulian, L.E., Cairncross, B., Tsikos, H., van Hunen, J., 2009. No evidence for thermogenic methane release in coal from the Karoo-Ferrar large igneous province. Earth Planet. Sci. Lett. 277, 204-212.

Guex, J., Morard, A., Bartolini, A., Morettini, E., 2001. Découverte d'une importante lacune stratigraphique à la limite Domérien-Toarcien: implications paléo-océanographiques. Bulletin de la Société Vaudoise des Sciences Naturelles 345, 277-284.

Hallam, A., 1997. Estimates of the amount and rate of sea-level change across the RhaetianHettangian and Pliensbachian-Toarcian boundaries (latest Triassic to early Jurassic). J Geol. Soc. London 154, 773-779.

Hesselbo, S.P., Jenkyns, H.C., 1995. A comparison of the Hettangian to Bajocian successions of Dorset and Yorkshire. In: Taylor, P.D. (Ed.), Field Geology of the British Jurassic. Geological Society of London, Bath, pp. 105-150.

Hesselbo, S.P., Pieńkowski, G., 2011. Stepwise atmospheric carbon-isotope excursion during the Toarcian Oceanic Anoxic Event (Early Jurassic, Polish Basin). Earth Planet. Sci. Lett. 301, 365-372.

Hesselbo, S.P., Gröcke, D.R., Jenkyns, H.C., Bjerrum, C.J., Farrimond, P., Morgans Bell, H. S., Green, O.R., 2000. Massive dissociation of gas hydrate during a Jurassic oceanic anoxic event. Nature 406, 392-395.

Hesselbo, S.P., Jenkyns, H.C., Duarte L.V., Oliveira, L.C.V., 2007. Carbon-isotope record of the Early Jurassic (Toarcian) Oceanic Anoxic Event from fossil wood and marine carbonate (Lusitanian Basin, Portugal). Earth Planet. Sci. Lett. 253, 455-470.

Howarth, A.S., 1985. Lithostratigraphy of the Staithes Sandstone and Clevand Ironstone formations (Lower Jurassic) of north-east Yorkshire, P. Yorks. Geol. Soc., 45, 261-275. Jenkyns, H.C., 1988. The early Toarcian (Jurassic) event: stratigraphy, sedimentary, and geochemical evidence. Am. J. Sci. 288, 101-151.

Jenkyns, H.C., 2010. Geochemistry of Oceanic Anoxic Events. Geochem. Geophys. Geosyst. 11. doi:10.1029/2009GC002788.

Jourdan, F., Féraud, G., Bertrand, H., Watkeys, M.K., Renne, P.R., 2008. The ${ }^{40} \mathrm{Ar} /{ }^{39} \mathrm{Ar}$ ages of the sill complex of the Karoo large igneous province: Implications for the 
Pliensbachian-Toarcian climate change. Geochem. Geophys. Geosyst. 9, Q06009, doi:10.1029/2008GC001994.

Kafousia, N., Karakitsios, V., Jenkyns, H.C., Mattioli, E., 2011. A Global event with a regional character: the Early Toarcian Oceanic Anoxic Event in the Pindos Ocean (Northern Peloponnese, Greece). Geological Magazine 148, 619-631.

Kaplan, M.E., 1978. Calcite pseudomorphoses from the Jurassic and lower Cretaceous deposits of northern East Siberia. Soviet geol. geophys. 12, 62-70.

Kemp, D.B., Coe, A.L., Cohen, A.S., Schwark, L., 2005. Astronomical pacing of methane release in the Early Jurassic period. Nature 437, 396-399, doi:10.1038/nature04037.

Kontorovich, A.E., Moskvin, V.I., Bostrikov, O.I., Danilova, V.P., Fomin, A.N., Fomichev, A.S., Kostyreva, E.A., Melenevsky, V.N., 1997. Main oil source formations of the West Siberian Basin, Petroleum Geoscience 3, 343-358.

Knyazev, V.G., Devyatov, V.P., Kutygin, R.V. Nikitenko, B.L, Schurygin, B.N, 2003. Zonal Standard of the Toarcian Stage of the North-East Part of Asia: Resp. red. S.P. Ermakova. - Yakutsk. YB of the SD RAS Publishing House.

Küspert, W., 1982. Environmental change during oil shale deposition as deduced from stable isotope ratios, in: Einsele, S., Seilacher A., (Eds.), Cyclic and Event Stratification. Springer, New York, pp. 482-501.

Léonide, P., Floquet, M., Durlet, C., Baudin, F., Pittet, B., Lécuyer, C., in press. Drowning of a carbonate platform as a precursor stage of the Early Toarcian global anoxic event (Southern Provence sub-Basin, South-east France). Sedimentology, DOI: 10.1111/j.1365-3091.2010.01221.x.

Macchioni, F., 2002. Myths and legends in the correlation between the Boreal and Tethyan Realms. Implications on the dating of the Early Toarcian mass extinction and the Oceanic Anoxic Event. Geobios Mém. Spec. 35, 150-164.

Mailliot, S., Mattioli, E., Guex, J., Pittet, B., 2006. The Early Toarcian anoxia, a synchronous event in the Western Tethys? An approach by quantitative biochronology (Unitary Associations), applied on calcareous nannofossils. Palaeogeogr. Palaeoclimatol. Palaeoecol. 240, 562-586.

Mattioli, E., Pittet, B., Bucefalo Palliani, R., Röhl, H.-J., Schmid-Röhl, A., Morettini, E., 2004. Phytoplankton evidence for timing and correlation of palaeoceanographical changes during the early Toarcian oceanic anoxic event (Early Jurassic). J. Geol. Soc. $161,685-693$. 
Marjanac, T., Steel, R.J., 1997. Dunlin Group Sequence Stratigraphy in the Northern North Sea: A Model for Cook Sandstone Deposition. AAPG Bull. 81, 276-292.

Mazzini, A., Svensen, H., Leanza, H.A., Corfu, F., Planke, S., 2010. Early Jurassic shale chemostratigraphy and $\mathrm{U}-\mathrm{Pb}$ ages from the Neuquén Basin (Argentina): Implications for the Toarcian Oceanic Anoxic Event. Earth Planet. Sci. 297, 633-645.

McArthur, J.M., Algeo, T.J., van de Schootbrugge, B., Li, Q., Howarth, R.J., 2008. Basinal restriction, black shales, Re-Os dating, and the Early Toarcian (Jurassic) oceanic anoxic event. Paleoceanography 23, PA4217.

Meyer, K.M., Kump, L.R., 2008. Oceanic euxinia in Earth history: Causes and consequences. Annu. Rev. Earth Planet. Sci., 36, 251-288, doi:10.1146/annurev. earth.36.031207.124256.

Nikitenko, B.L., 2008. The Early Jurassic to Aalenian paleobiogeography of the arctic realm: Implication of microbenthos (foraminifers and ostracodes). Stratigraphy and Geological Correlations 16, 59-80.

Nikitenko B.L., 2009. Jurassic Stratigraphy, Palaeobiogeography and Biofacies of Siberia on Microfauna (Foraminifers and Ostracodes), 680 p. ("Nonparel" Publishing House, Novosibirsk).

Nikitenko, B.L., Mickey, M.B., 2004. Foraminifera and ostracodes across the PliensbachianToarcian boundary in the Arctic Realm (stratigraphy, paleobiogeography and biofacies). J. Geol. Soc. Spec. Publ. 230, 137-174.

Parisi, G., Ortega-Huertas, M., Nocchi, M., Palomo, I., Monaco, P., Martinez, F. 1996. Stratigraphy and geochemical anomalies of the early Toarcian oxygen-poor interval in the Umbria-Marche Apennines (Italy). Geobios, 29, 469-484.

Prauss, M., Ligouis, B., Luterbacher, H., 1991. Organic matter and palynomorphs in the 'Posidonienschiefer' (Toarcian, Lower Jurassic) of southern Germany. J. Geol. Soc. Special Publication 58, 335-351.

Revelle, R., 1990. Sea Level Change, 234 p (National Academy Press, Studies in Geophysics, Washington DC).

Riding, J.B., Fedorova, V.A., Ilyina, V.I., 1999. Jurassic and Lowermost Cretaceous dinoflagellate cyst biostratigraphy of the Russian Platform and Northern Siberia, Russia. American Association of Stratigraphic Palynologists Foundation Contributions Series $36,1-184$. 
Röhl, H.-J., Schmid-Röhl, A., 2005. Lower Toarcian (Upper Liassic) black shales of the Central European Epicontinental Basin: a sequence stratigraphic case study from the SW German Posidonia Shale (Lower Toarcian). SEPM Spec. Publ. 82, 165-189

Röhl, H.J., Schmid-Röhl, A., Oschmann, W., Frimmel, A., Schwark, L., 2001. The Posidonia Shale (Lower Toarcian) of SW-Germany: an oxygen-depleted ecosystem controlled by sea level and palaeoclimate. Palaeogeogr. Palaeoclimatol. Palaeoecol. 165, 27-52. 240 .

Sabatino, N., Neri, R., Bellanca, A., Jenkyns, H.C., Baudin, F., Parisi, G., Masetti, D., 2009. Carbon-isotope records of the Early Jurassic (Toarcian) oceanic anoxic event from the Valdorbia (Umbria-Marche Apennines) and Monte Mangart (Julian Alps) sections: palaeoceanographic and stratigraphic implications. Sedimentology 56, 1307-1328.

Sahagian, D., Pinous, O., Olferiev, A., Zakharov, V., 1996. Eustatic curve for the Middle Jurassic-Cretaceous based on Russian platform and Siberian stratigraphy: zonal resolution. AAPG Bull. 80, 1433-58.

Schouten, S., Van Kaam-Peters, H.M.E, Rijpstra, W.E.C, Schoell, M., Sinninghe Damste, J.S., 2000. Effects of an Oceanic Anoxic Event on the stable carbon isotopic composition of early Toarcian carbon. Am. J. Sci. 300, 1-22.

Selleck, B.W., Carr, P.F., Jones, B.G., 2007. A review and synthesis of glendonites (pseudomorphs after ikaite) with new data: assessing applicability as recorders of ancient coldwater conditions. J. Sediment. Res. 77, 980-991.

Shurygin, B.N., 2005. Lower and Middle Jurassic Biogeography, Facies and Stratigraphy in Siberia Based on Bivalve Molluscs, 154 p. (Novosibirsk Academic Publishing House "Geo", Novosibirsk).

Suan, G., Pittet, B., Bour, I., Mattioli, E., Duarte, L.V., Mailliot, S., 2008. Duration of the Early Toarcian carbon isotope excursion deduced from spectral analysis: consequence for its possible causes. Earth Planet. Sci. Lett. 267, 666-679.

Suan, G., Mattioli, E., Pittet, B., Lécuyer, C., Suchéras-Marx, B., Duarte, L.V., Philippe, M., Reggiani, M.L., Martineau, F., 2010. Secular environmental precursors to Early Toarcian (Jurassic) extreme climate changes. Earth Planet. Sci. Lett. 290, 448-458.

Svensen, H., Planke, S., Chevallier, L., Malthe-Sorenssen, A., Corfu, F., Jamtveit, B., 2007. Hydrothermal venting of greenhouse gases triggering Early Jurassic global warming. Earth Planet. Sci. Lett. 256, 554-566. 
Traverse, A., 2007. Paleopalynology. Second Edition. 813 p. (Topics in Geobiology 28, Springer, Dordrecht, The Netherlands).

Vakhrameev, V.A., 1991. Jurassic and Cretaceous floras and climates of the Earth. Cambridge University Press.

van Breugel, Y., Baas, M., Schouten, S., Mattioli, E., Sinninghe Damsté, J.S., 2006. Isorenieratane record in black shales from the Paris Basin, France: Constraints on recycling of respired $\mathrm{CO}_{2}$ as a mechanism for negative carbon isotope shifts during the Toarcian oceanic anoxic event. Paleoceanography 21, PA4220, doi : 10.1029/2006PA001305.

van de Schootbrugge, B., McArthur, J.M., Bailey, T.R., Rosenthal, Y., Wright, J.D., Miller, K.G., 2005. Toarcian oceanic anoxic event: An assessment of global causes using belemnite C isotope records. Paleoceanography 20, PA3008, doi:10.1029/2004PA001102.

van de Schootbrugge, B., Harazim, D., Sorichter, K., Oschmann, W., Fiebig, J., Püttmann, W., Peinl, M., Zanella, F., Teichert, B.M.A., Hoffmann, Stadnitskaia, J.A., Rosenthal, Y., 2010. The enigmatic ichnofossil Tisoa siphonalis and widespread authigenic seep carbonate formation during the Late Pliensbachian in southern France. Biogeosciences 7, 3123-3138.

Wignall, P.B., 1991. Model for transgressive black shales? Geology 19, 167-170.

Wignall, P.B., Newton, R., 1998. Pyrite framboid diameter as a measure of oxygen deficiency in ancient mudrocks. Amer. J. Sci. 298, 537-552.

Wignall, P.B., Newton, R.J., Little, C.T.S., 2005. The timing of paleoenvironmental change and cause- and -effect relationships during the Early Jurassic mass extinction in Europe. Am. J. Sci. 305, 1014-1032.

Wignall, P.B., Bond, D.P.G., Kuwahara, K., Kakuwa, Y., Newton, R.J., Poulton, S.W., 2010. An 80 million year oceanic redox history from Permian to Jurassic pelagic sediments of the Mino-Tamba terrane, SW Japan, and the origin of four mass extinctions. Global Planet. Change 71, 109-123.

Wilkin, R.T., Barnes, H.L., Brantley S.L., 1996. The size distribution of framboidal pyrite in modern sediments: An indicator of redox conditions. Geochim. Cosmochim. Ac. 60, 3897-3912.

Zakharov, V.A., Bogomolov, Y.I., Ilyina, V.I., Konstantinov, A.G., Kurushin, N.I., Lebedeva, N.K., Meledina, S.V., Nikitenko, B.L., Sobolev, E.S., Shurygin, B.N., 1997. Boreal 

38, 927-956.

808

809

810

811

\section{$812 \quad$ Figure captions}

813

814

815

816

817

818

819

820

821

822

823

824

825

826

827

828

829

830

831

832

833

834

835

836

837

838

839 417.

Zakharov, V.A., Shurygin, B.N., Ilyina, V.I., Nikitenko, B.L., 2006. Pliensbachian-Toarcian

Biotic Turnover in North Siberia and the Arctic Region. Stratigr. Geol. Correl. 14, 399-

Fig. 1. Location and biostratigraphy of the sections studied and localities mentioned in the text. The two left hand panels show the geographical locations. The right hand panel depicts the palaeogeography of the Early Toarcian; this palaeogeographic map was modified from Nikitenko and Mickey (2004). Abbreviations: PR = Polovinnaya River; AB = Anabar Bay; $\mathrm{KR}=$ Kelimyar River; WSB $=$ W Siberian Basin.

Fig. 2. Biostratigraphy and lithostratigraphy of the sections studied. A) Biostratigraphy of the Olenek-Kelimyar Rivers area compared to equivalent Boreal and NW European ammonite zones. The relationships between different biostratigraphical schemes of the Olenek-Kelimyar Rivers area have been constructed using new macropalaeontological and micropalaeontological data from several sections in this area (see list and location of these sections in Knyazev et al, 2003). B) biostratigraphy, lithological characteristics and proposed correlation of the Pliensbachian-Toarcian sections studied from N Siberia. The ammonite biostratigraphy of the Kelimyar River section has been refined using the well-constrained foraminifera and dinoflagellate cyst zones of the section and their relationships with ammonite zones in several coeval sections nearby. The foraminifera and dinoflagellate cyst biostratigraphy of the Polovinnaya River section is from this study and that of Anabar Bay section is from Riding et al. (1999) and Knyazev et al. (2003); the bivalve, dinoflagellate cyst and foraminifera zones from these two sections were used to infer tentatively the positions of ammonite zones by comparison with other sections (see text). Abbreviations: $a=$ antiquum; falc $=$ falciferum $;$ com $=$ commune $;$ braun $=$ braunianus $;$ A-zone $=$ ammonite zone; F-zone $=$ foraminifera zone; D-zone $=$ dinoflagellate cyst zone.

Fig. 3. Evidence for near-freezing conditions in polar regions prior to the T-OAE. A) In situ glendonites (arrows) from the Upper Pliensbachian of Anabar Bay; B) Isolated glendonite specimen from the Upper Pliensbachian of Anabar Bay (scale bar=1 cm); C) and D) Thin 
840

841

842

843

844

845

846

847

848

849

850

851

852

853

854

855

856

857

858

859

860

861

862

863

864

865

866

867

868

869

870

871

872

873

section of the specimen depicted in B, showing the contact between the stellate margin of the glendonite and the fine-grained matrix; note also the granular texture of the replacive calcite (scale bars $=500 \mu \mathrm{m} ; \mathrm{D}$, crossed nicols); E) and F) An isolated limestone boulder (maximum width $=\sim 20 \mathrm{~cm}$ ) encrusted by Harpax bivalves from the Upper Pliensbachian homogenous siltstone at Kelimyar River.

Fig. 4. Total Organic Carbon (TOC), Hydrogen Index, pyrite framboid and organic carbon isotope ( $\delta^{13} \mathrm{C}_{\text {TOC }}$ data) for the Pliensbachian and Toarcian strata of N Siberia. Each point of the pyrite framboid profile represents the average size of 30 pyrite framboids and the error bars are $95 \%$ confidence intervals. See Fig. 1 for details on the biostratigraphy of the sections studied. a. $=$ antiquum; braun. $=$ braunianus; falc. $=$ falciferum; com. $=$ commune; A-zone $=$ ammonite zone.

Fig. 5. Origin of the sedimentary organic matter from the Pliensbachian and Toarcian strata of N Siberia and relationships with its carbon isotopic composition. A) Hydrogen Index (HI) versus $\mathrm{T}_{\max }$ values and B) versus Oxygen Index (OI) for Polovinnaya River and Kelymiar River samples, illustrating the kerogen types and probable origin of the organic matter; C) Hydrogen index versus $\delta^{13} \mathrm{C}_{\mathrm{TOC}}$ values obtained for Polovinnaya River and Kelymiar River samples; D) TOC versus $\delta^{13} \mathrm{C}_{\mathrm{TOC}}$ values obtained for Anabar Bay, Polovinnaya River and Kelymiar River samples. AB=Anabar Bay; $\mathrm{KR}=$ Kelimyar River; $\mathrm{PR}=$ Polovinnaya River. TOC $=$ total organic carbon content of the samples analyzed.

Fig. 6. Comparison of climatic, geochemical and biotic records of the T-OAE between polar and tropical latitudes. A) Climatic and biotic events in the Arctic. The level of the mass extinction and main biotic events are from Zakharov et al. (2006); B) Chronostratigraphy, Total Organic Carbon (TOC), Hydrogen Index and organic carbon isotope $\left(\delta^{13} \mathrm{C}_{\mathrm{TOC}}\right)$ data from Kelimyar River; C) Chronostratigraphy, TOC, Hydrogen Index and $\delta^{13} \mathrm{C}_{\mathrm{TOC}}$ data from Dotternhausen (filled circles) and Zimmern (squares) modified from Küspert (1982), Prauss et al. (1991) and Röhl et al. (2001) and estimated duration of the CIE following Cohen et al. (2007) and Suan et al. (2008); D) Seawater palaeotemperatures derived from the oxygen isotope composition of belemnites from Dera et al. (2009) and the mass extinction level at low-latitudes from Caswell et al. (2009). a. = antiquum; bifr. = bifrons; braun. = braunianus; ten. $=$ tenuicostatum; v. = variabilis; U.T. = Upper Toarcian; A-zone = ammonite zone. 
874 Fig. 7. Organiccarbonisotope ${ }^{\mathrm{TM}}{ }^{13} \mathrm{C}_{\mathrm{TOC}}$ ) and Total Organic Carbon (TOC) trends in polar and 875 tropical areas during the Pliensbachian-Toarcian interval. A) Shallow water section of 876 Anabar Bay, N Siberia; B) Deep shelf record of Kelimyar River, N Siberia; C) Deep water 877 record of Dotternhausen and Zimmern, SW Germany (modifed from Küspert, 1982, Prauss et 878 al., 1991 and Röhl et al., 2001); D) Shallow water record of NE France (modified from van 879 Breugel et al., 2006); E) Open-ocean record of Valdorbia, central Italy (isotope and TOC data 880 modified from Sabatino et al., 2009; Biostratigraphy from Bilotta et al., 2010). a. = antiquum; 881 bifr. = bifrons; braun. = braunianus; mir. = mirabilis; serp. $=$ serpentinus; ten.$=$ 882 tenuicostatum; U.T. = Upper Toarcian; A-zone = ammonite zone; N-zone, nannofossil zone. 883 


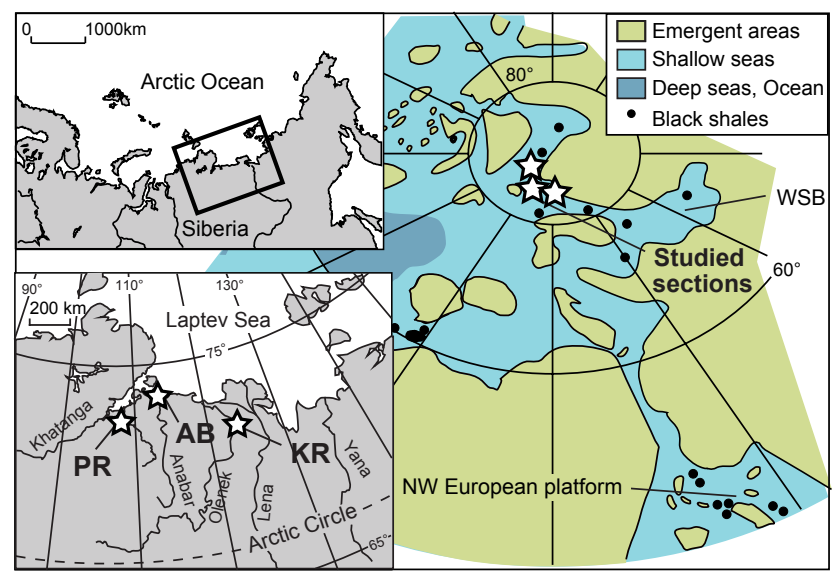

Suan et al., Fig. 1 


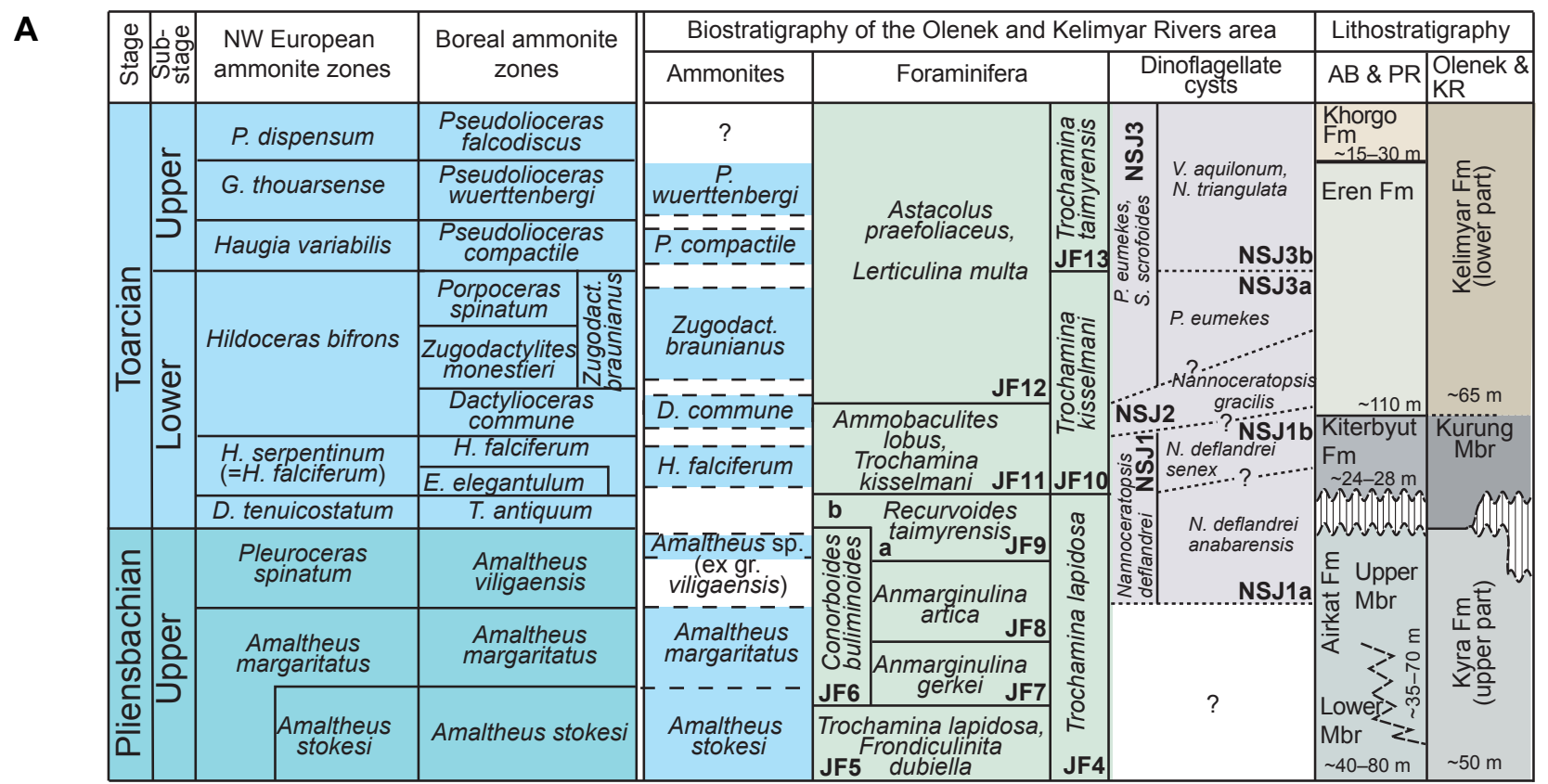

B

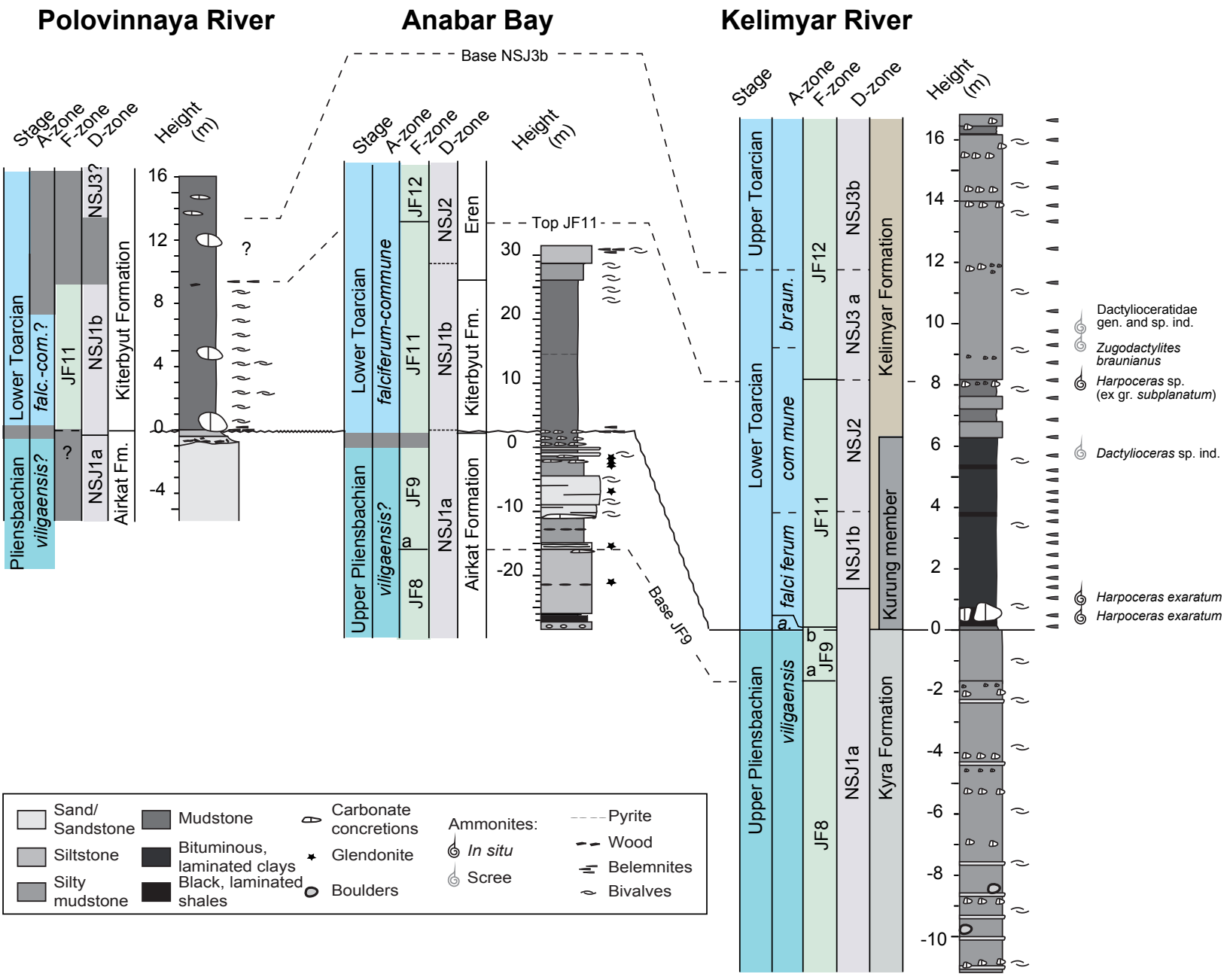

Suan et al., Fig. 2 


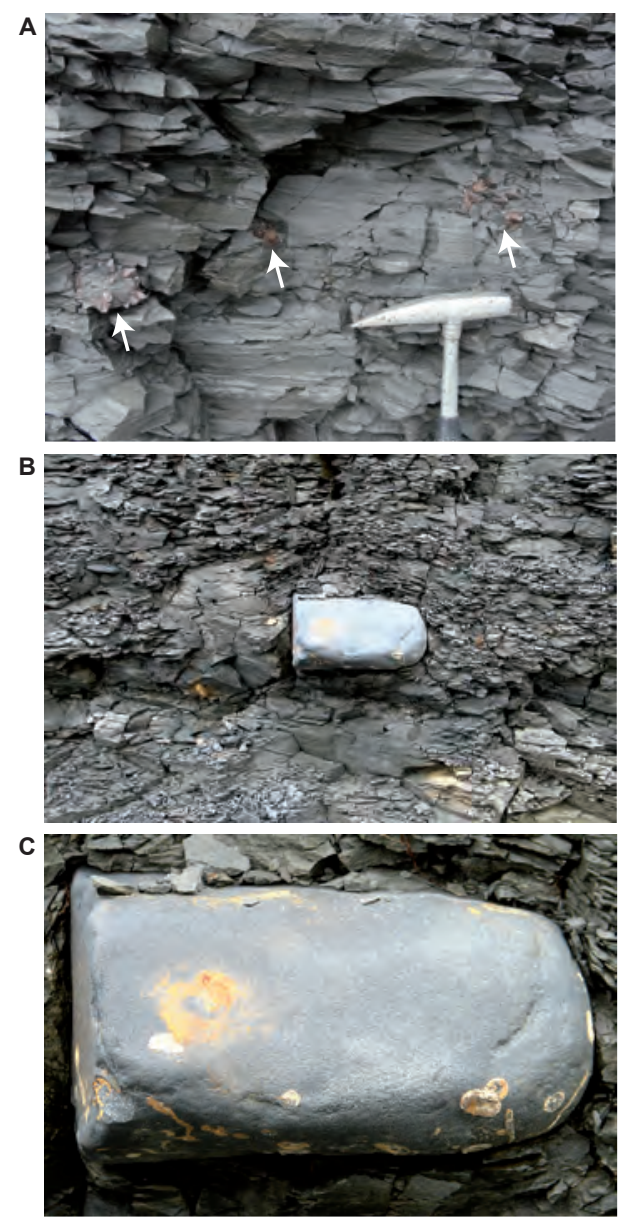

Suan et al., Fig. 3 


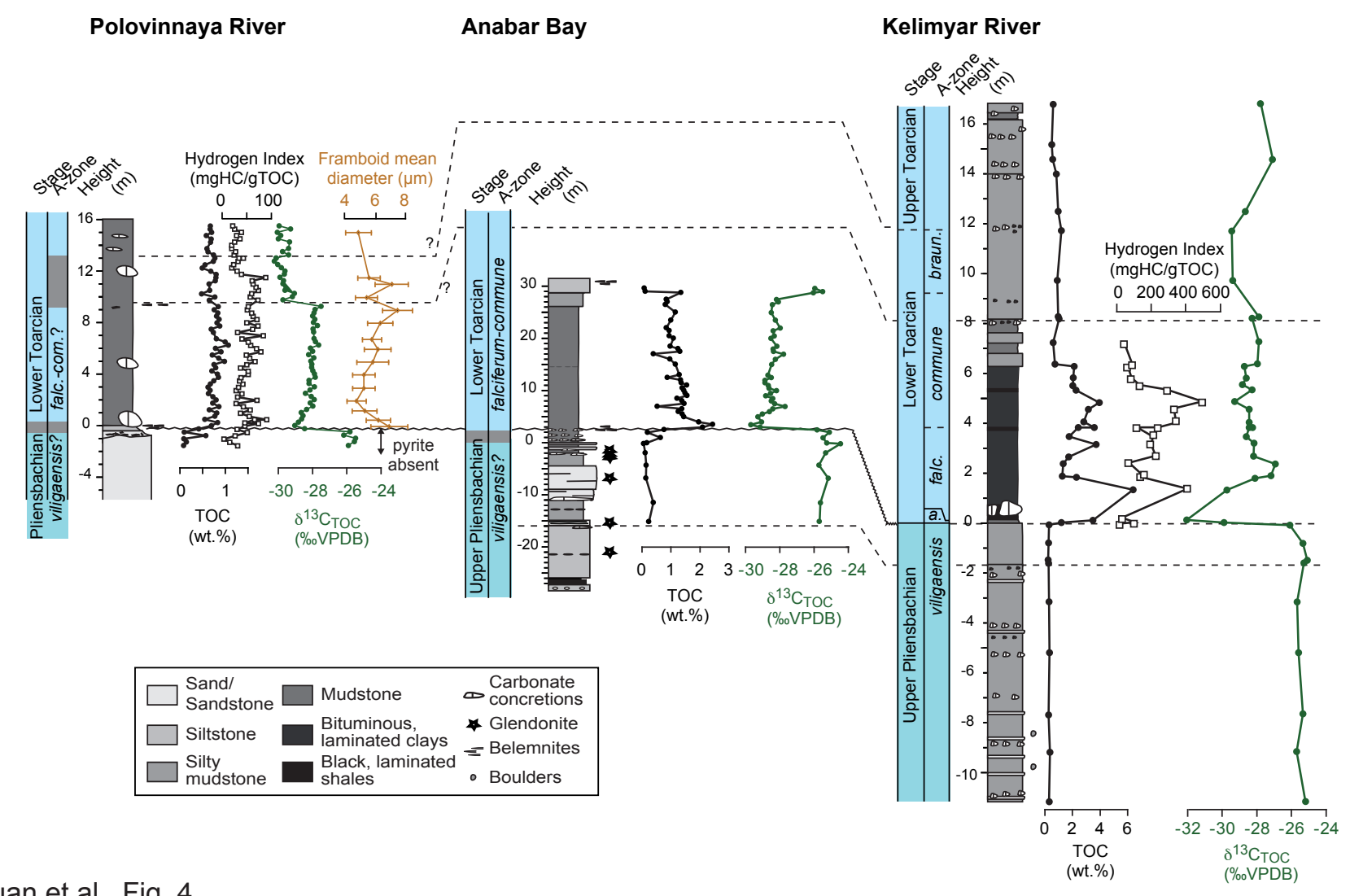

Suan et al., Fig. 4 

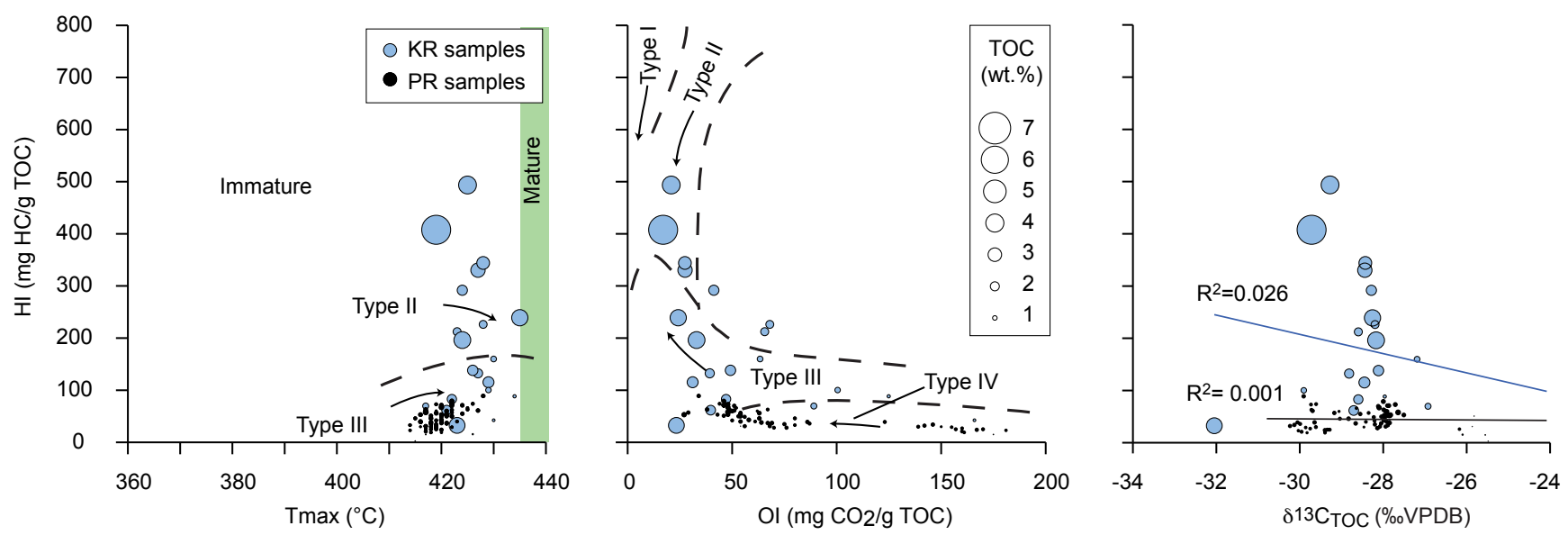

Suan et al., Fig. 5 


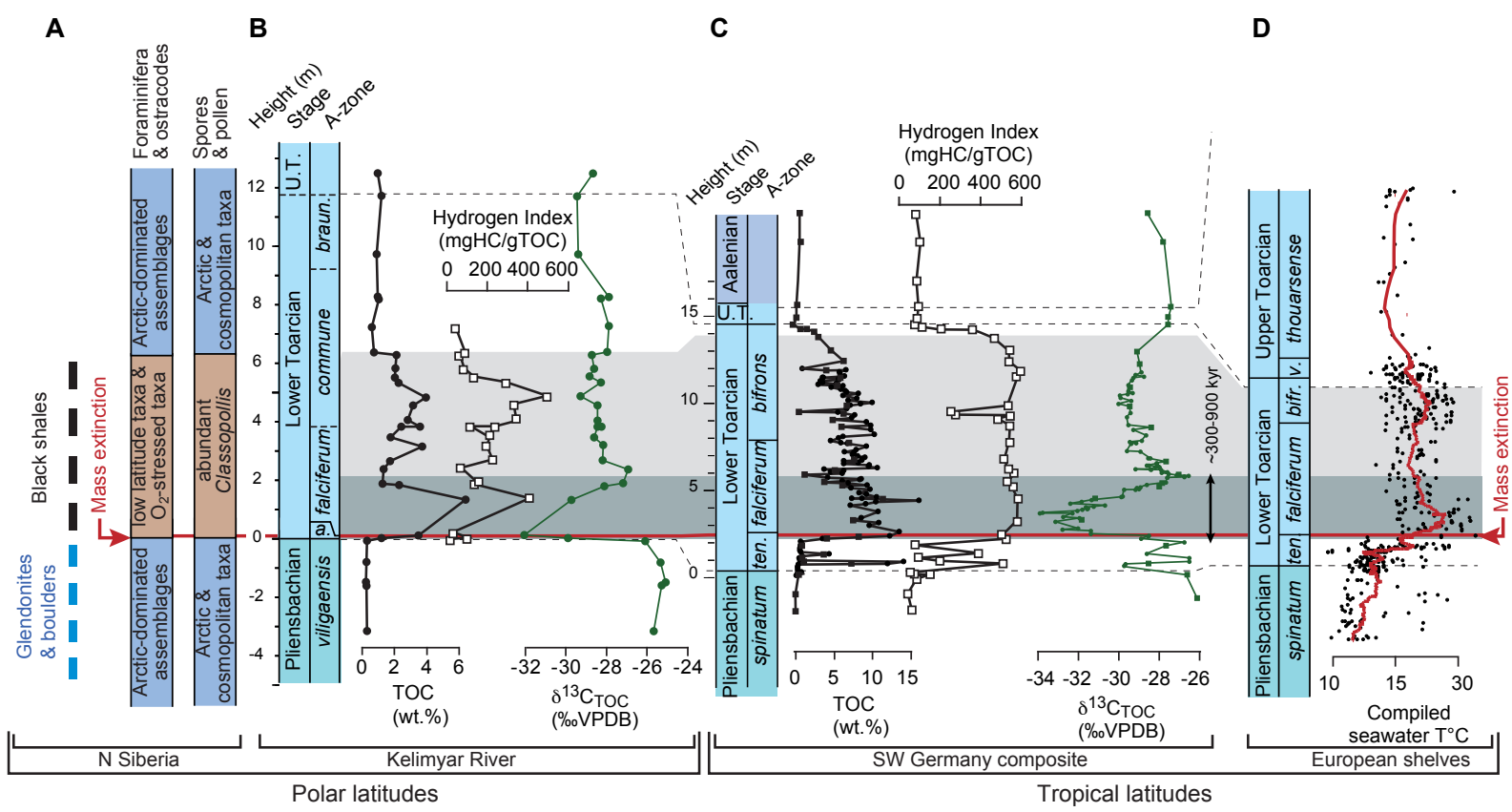

Suan et al., Fig. 6 


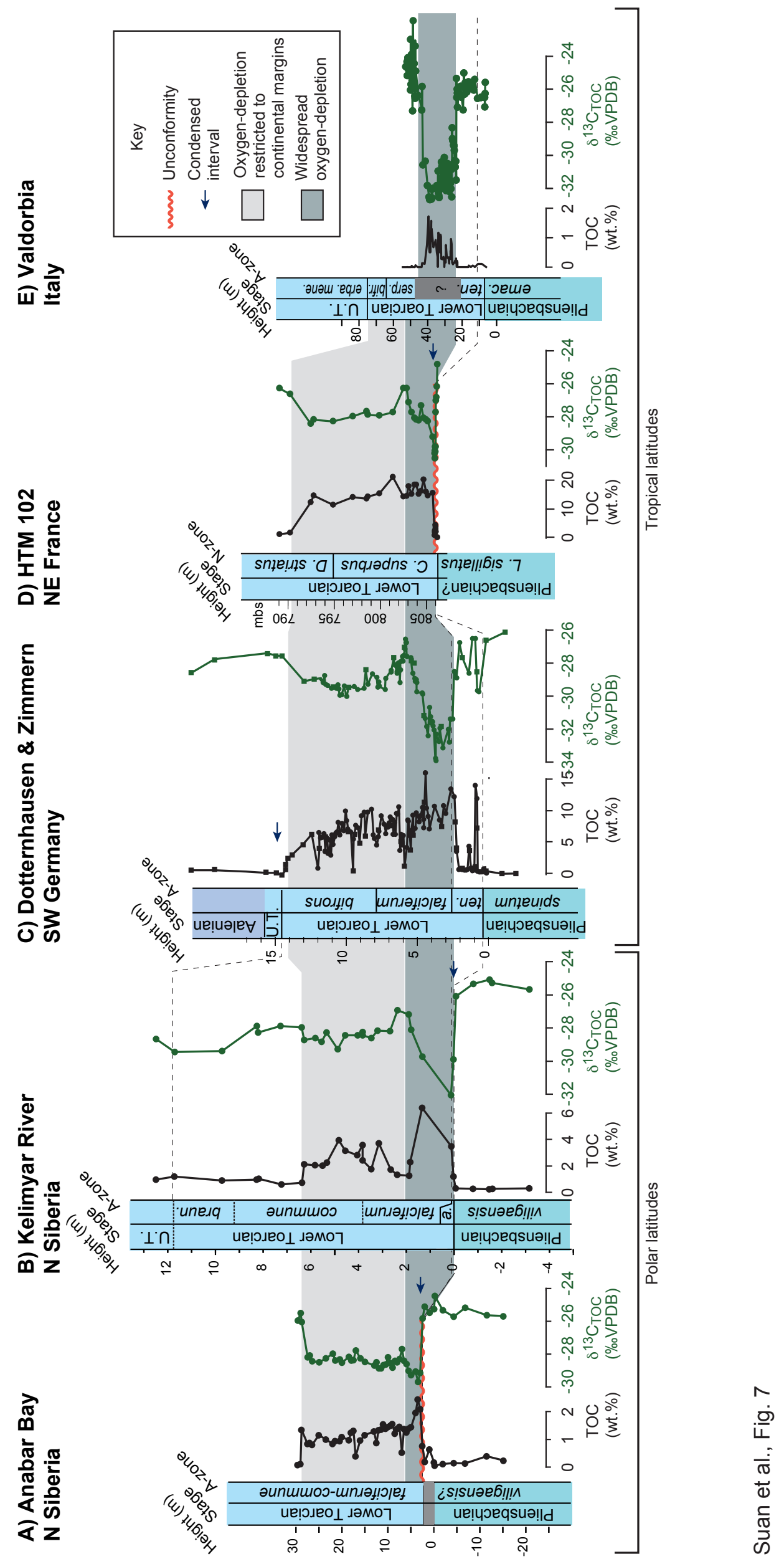

